\title{
Past, present and future of Virtual Reality: Analysis of its technological variables and definitions
}

\author{
Adriana Paíno Ambrosio ${ }^{1}$ and M. Isabel Rodríguez Fidalgo 2 \\ ${ }^{1}$ University of Salamanca. \\ e-mail: adriana.paino@usal.es \\ ORCID iD: http://orcid.org/0000-0003-3817-6071 \\ ${ }^{2}$ University of Salamanca. \\ e-mail: mrfidalgo@usal.es \\ ORCID iD: http://orcid.org/0000-0001-5167-0272
}

Submitted: 23 March 2019. Accepted: 15 May 2019

\begin{abstract}
Developments in Virtual Reality (VR) technology are currently arousing great scientific interest because in just a few years, VR has found its niche not only in the specialised public, but also in society in general and in different contexts, thanks to its many uses in different contexts and the decreasing price of VR viewing devices. To many, this technology may appear to be a novelty of the $21^{\text {st }}$ century, but its origins go back several decades. Taking into account these aspects, this article aims to analyse the past and present of VR from two perspectives: one focused on its technological development and one on its conceptual evolution. This historical overview, in turn, will allow us to address the future applications of VR in different disciplines. The study provides the reader with an indepth analysis of VR that will contribute to the understanding of this technology and its uses.
\end{abstract}

KEYWORDS: VR; HMD; VR glasses; History; Technology; Applications; Virtual environments.

Citation / Cómo citar este artículo: Paíno Ambrosio, Adriana and Rodríguez Fidalgo, M. Isabel (2020) "Past, present and future of Virtual Reality: Analysis of its technological variables and definitions" Culture \& History Digital Journal, 9 (1): e010. https://doi.org/10.3989/chdj.2020.010

RESUMEN: Pasado, presente y futuro de la Realidad Virtual: análisis a partir de las variables tecnológica y de definición del término.- Hoy en día todo lo relacionado con la Realidad Virtual (RV) despierta un gran interés científico. Tal es así que en pocos años ha conseguido hacerse un hueco no solo entre el público especializado, sino también entre la sociedad en general, ya que, sus aplicaciones son muchas y en diferentes contextos. Este hecho ha sido posible en gran medida gracias al imparable desarrollo tecnológico y al abaratamiento de los dispositivos de visualización. Parecería, por tanto, que esta tecnología es una novedad del sigo XXI, pero lo cierto es que sus orígenes se remontan varias décadas en el pasado. Teniendo en cuenta estos aspectos, este artículo tiene como objetivo analizar el pasado y el presente de la RV desde una doble perspectiva: la que tiene que ver, por una parte, con su desarrollo tecnológico y, por otra, con la definición del término. Dicho recorrido histórico, a su vez, permitirá abordar las perspectivas de futuro de la RV desde el punto de vista de sus aplicaciones dentro de diferentes disciplinas. Todo ello dotará al lector de una visión en profundidad acerca de la tecnología de la RV que servirá para comprender.

PALABRAS CLAVE: RV; HMD; Gafas de RV; Historia; Tecnología; Aplicaciones; Entornos virtuales.

Copyright: (C) 2020 CSIC. This is an open-access article distributed under the terms of the Creative Commons Attribution 4.0 International (CC BY 4.0) License. 


\section{INTRODUCTION}

On 21 February 2016, Mark Zuckerberg took the stage at the Mobile World Congress in Barcelona to talk about Virtual Reality (VR). The image of the founder of Facebook walking down the aisle surrounded by more than 10,000 people while wearing a VR headset went around the world, reflecting the growing importance of this technology, which has quickly found its niche in the market, including the non-specialised public, and has made tech companies to compete to lead the production of these devices.

From the technological point of view, the main innovation introduced by VR has to do with the possibility of "immersion"; that is, of "entering" into the narrative through the creation of a virtual world. However, this possibility is not new. VR is a consequence of the succession of technological advances, much of which are linked to cinema and the search for new simulation techniques. To be precise, the first VR experiences started in the 1960s, when Morton Heilig and Ivan Sutherland developed the first devices capable of creating the illusion of three-dimensionality. Several decades later, tech companies set their sights on VR once again, challenging its perception as a "fad" and consolidating its development and sales within the technological market, thanks to its many applications.

Based on a systematic literature review of the origins and development of VR, this study aims to delve into its technological evolution, which in turn will allow us to approach the evolution of its definition and identify its future applications.

\section{METHODS}

From the methodological point of view, this study is based on a systematic review of the scientific works published about this object of study. This review of documentary sources has allowed us to achieve the following research objectives:

1 Analyse the historical evolution of VR in conceptual terms.

2 Analyse the historical evolution of VR in technological terms.

3 Identify the possible applications of VR across different fields of knowledge.

\section{CONCEPTUAL APPROXIMATION: REFERENCES IN LITERATURE, EMERGENCE OF THE TERM AND PROPOSED DEFINITIONS}

Román Gubern points out that Alice's Adventures in Wonderland (1865) is "the first mythical and fabulist formulation of the VR project" (Gubern, $1996 \mathrm{p}, 161)$. Specifically, the author refers to the last passage of Carroll's original novel, when Alice's sister dreams of the same world and the same characters Alice just dreamt of, as if her sister "had entered the same virtual scenario that she (Alice) just left" (Gubern, 1996:161). This scene, which proposes the "permanence of virtual scenarios", Gubern continues, "anticipated something that engineers would eventually build with computer tools a century later" (1996:161). Although, seventy years before Carroll, Stanley Weinbaum had already anticipated a VR system in Pygmalion's Spectacles (1935), a short science fiction story whose main character meets an inventor -Professor Ludwig- who has developed a visualisation system that allows the user to interact with a fictional world through all the senses (Rubio-Tamayo and Gértrudix, 2016).

For other authors like Eric Steinhart (1997), Gottfried Wilhelm Leibniz is one of the first to refer to a possible VR. In The Palace of Destinies (1710), the philosopher refers to a structure capable of stimulating all the senses and generating experiences in real time in non-existent environments: "an organised system of virtual worlds available for human perceptual exploration, along with an interface for exploring them" (quoted in Steinhart, 1997). However, as Parés and Parés (2010) point out, Leibniz's idea remained on paper until 1962, when it begins to materialise an incipient VR technology. These literary examples, much older than the first VR systems, reflect an interest in the possibility of "travelling" to other worlds, either through a dream, like Alice did, or through special glasses, like those developed by Professor Ludwig, which decades later became the preferred device to experience VR, but retaining the idea that people can travel without having to move physically.

As the previous sections suggest, VR was very close to literary and cinematographic fiction. That is why we found examples such as William Gibson and his novel Neuromancer (1984), which explores cyberspace even before the emergence of the Internet and computer-generated artificial environments, and Neal Stephenson's Snow Crash (1992), which introduces the concept of metaverse, as a virtual world in which people can interact with each other without physical limitations.

The term VR became popular in the late 1980s and its coining is attributed to the founder of VPL Research Inc, Jaron Lanier, although it was the French playwright Antonin Artaud who used the term réalité virtuelle for the first time, in 1938, to define theatre in his essay Le théâtre et son doublé ("The theatre and its double"). Artaud referred to theatre as a mirage existing "between the world in which the characters, objects, images, and in general all those elements that constitute the virtual reality of the theatre develops, and the purely fictitious and illusory world in which the symbols of alchemy evolved" (in Artaud 1978 $\mathrm{p}, 54)$. Although Artaud's use of the term is very different from the current conception of VR, it is interesting to compare it with the theatre to the extent that the audience, faced with a theatrical representation, is immersed in an imaginary world; an immersion that manages to endow representations with resemblance to 
reality (Ekweariri, 2013). However, it was the multifaceted Lanier who coined the term, applied to computer-generated simulated environments. In an interview for Whole Earth Review, published in 1989, Lanier defined VR in the following way:

\begin{abstract}
Virtual Reality is not a computer. We are speaking about a technology that uses computerized clothing to synthesize shared reality. It recreates our relationship with the physical world in a new plane, no more, no less. It doesn't affect the subjective world; it doesn't have anything to do directly with what's going on inside your brain. It only has to do with what your sense organs perceive. The physical world, the thing on the other side of your sense organs, is received through these five holes, the eyes, and the ears, and the nose, and the mouth, and the skin [...] Before you enter the Virtual Reality you'll see a pile of clothing that you have to put on in order to perceive a different world than the physical world. The clothing consists of mostly a pair of glasses and a pair of gloves. (Lanier, 1989 p, 110)
\end{abstract}

Lanier uses a multi-sensory approach, linking VR with the stimulation of all the senses (not just sight). Thus, he links VR with the use of different wearable artifacts that allow the user to perceive the virtual world as if it were the physical world, creating the illusion of "being there", so that VR is restricted, according to Lanier, to the scope of the simulation. After him, many authors have tried to define VR, although not from the same point of view, so there are almost as many definitions as there are authors who have approached this object of study. Thus, while some authors have focused on the technological component (mainly based on hardware), others have adopted a psychological perspective or a philosophical view. In many cases, these three dimensions converge in the same definition. For example, Brudniy and Demilhanova (2012) argue that the VR construct is created by the interaction of these technological, psychological and philosophical perspectives.

Some of the most commonly used definitions of VR are the ones proposed by Bell and Fogler (1995), Biocca and Levy (1995), Burdea and Coiffet (2003), Coates (1992), Del Pino (1995), Greenbaum, (1992), Gubern (1996), Heim (1993), Pimentel and Teixeira (1995), Rheingold (1994) and Sherman and Craig (2003). Some of these definitions are presented below:

- For Bell and Fogler, VR is "a computer interface characterised by high levels of immersion, credibility and interaction, whose objective is to make users believe that they are really within a computer-generated environment" (Bell and Fogler, 1995, p. 2).

- For Biocca and Levy, it is an interface that tries to "achieve full immersion of human sensory channels in a vital experience generated by computer" (Biocca and Levy, 1995 p. 17).

- For Coates (1992), VR are electronic simulations that the user experiences with the help of a VR headset.
- For Greenbaum (1992), it is an alternative world made of computer-generated images that respond to users' movements, thanks to use of devices such as goggles and gloves.

- For Pimentel and Teixeira, the term refers to "an immersive and interactive computer-generated experience" (Pimentel and Teixeira, 1995, p. 11).

One of the most interesting definitions is provided by Gubern, for whom VR is:

[...] a computer system that generates synthetic environments in real time within an illusory reality (illudere: deceive), because it is a perceptual reality without objective support, without res extensa, since it only exists within the computer. (Gubern, 1996 p. 156)

Gubern's concept of "illusory reality", which in this case refers to the deceit of the user's senses by VR, is not new and is reminiscent of Plato, who claimed that pictorial manifestations could deceive people and make them believe that they were watching the real referent, not a copy (Plato, trad. in 1966). This idea that questions the veracity of perceptions and the difficulty of distinguishing between reality and fiction has been present since the beginnings of VR, especially in the literature and cinema, in films like Brainscan (1994), Ghost in the Shell (1995), eXistenZ (1999) and The Matrix (1999) (Roas, 2009 p. 101). In these films the real world and the virtual world appear to be separated and a priori do not interfere with each other, until the barrier between the two is broken, as it happens in The Matrix, where the protagonist dies in the virtual world and, as a consequence, also in the real world (Roas, 2009).

Returning to the proposed definitions, Luis Del Pino conceives VR as "an interactive system that allows synthesising a fictitious three-dimensional world that creates in the user an illusion of reality" (Del Pino, 1995, p. 19). This definition includes four concepts: synthetic capacity, interactivity, three-dimensionality and illusion of reality. As we can see, it retakes the concept of "illusion", which is a fundamental characteristic for the credibility of the virtual environment. In addition, Del Pino (1995) also establishes a series of factors that will make the illusion of reality more intense: that the system is capable of stimulating more than one of the user's senses, that the user can interact and influence the state of the virtual world and that the virtual world 'behaves' as if it were real.

Rheingold, for his part, does not establish a definition as such, but offers a description from which one can extract the components that, according to him, are involved in VR, such as: artificial world, immersion, interaction and three-dimensional graphics (Rheingold, 1994 pp. 2021). Rheingold, like Lanier, also refers to the multisensory stimulus, referring in this case not only to the sight (with the use of a Head-Mounted Displays, also known as HMD), but also to three-dimensional sound and the sense of touch, insofar as the user can "manipulate and touch" the objects of the artificial world. 
In Metaphysics of Virtual Reality (1993), Michael Heim also identifies seven elements that, in his opinion, intervene in VR: simulation, interaction, artificiality, immersion, telepresence, body immersion and network communication. For Burdea and Coiffet, the main characteristics of VR are reduced to "the three I's": Immersion, Interaction and Imagination (2003 p. 3). These authors also provide a definition that conceives VR as "a high-end user interface that involves the user in a real-time simulation in which he or she can interact across multiple sensory channels. These sensory modalities are visual, auditory, tactile, olfactory and gustatory" (Burdea and Coiffet, 2003 p. 3).

Sherman and Craig (2003), meanwhile, define four key elements of VR: Virtual world, immersion, sensory feedback and interactivity. Based on these elements, they define VR in its more global view as:

\footnotetext{
a medium composed of interactive computer simulations that sense the participant's position and actions and replace or augment the feedback to one or more senses, giving the feeling of being mentally immersed or present in the simulation (a virtual world). (Sherman and Craig: 2003 p. 13)
}

Based on the contributions made by the different authors who have studied VR, we can extract three elements that will characterize this technology and are commonly accepted by all authors: immersion (multisensory), presence and interactivity. While these elements are not the only ones necessary for a given experience to be considered VR, they are the ones that will directly affect the way the user relates to the virtual world and gets involved in that experience.

\section{PAST AND PRESENT OF VR: FROM ALICE'S ADVENTURES IN WONDERLAND TO OCULUS RIFT}

Five great stages can be identified in the technological history of VR, from the oldest predecessors linked to the first theories of vision, stereoscopy and anaglyphs, to the current devices on the market:

\section{From 1833 to 1950: remote predecessors}

Since the mid- $19^{\text {th }}$ century, there were many inventions that contributed to the birth of VR technology as such. For example, British scientist Charles Wheatstone and his studies on vision gave rise to the invention of the stereoscope (in 1838), a device that creates the illusion of three-dimensional depth, which can be considered the first predecessor of the VR viewer; and the anaglyph process developed by German physicist Wilhelm Roll Mann in 1853 and later perfected by Louis Ducos du Hauron (1891), which enabled three-dimensional photography through the juxtaposition of two images with complementary colours (anaglyphs). Both stereoscopy and anaglyphs are strongly linked to the development of 3D viewers.
Twenty years later, Hugo Gernsback, the father of science fiction, invented the "teleyeglasses" (1936), a portable, battery-operated, head-mounted display that aimed to create "immersive" television, although it was not until 1963 when this invention was presented to the public (in O'Neill, 1963). Gernsback was certainly a visionary and already in the 1920s he studied the possibility of avoiding unnecessary travelling through telepresence. In the February 1925 issue of Science and Inventions magazine, edited by Gernsback himself, he spoke of a future invention that would have applications in the field of medicine and would allow physicians to take care of their patients remotely by means of a device called "teledactyl" (Novak, 2012).

\section{From 1950-60 to the first half of the 1970s: first devices}

The first direct predecessor of VR is the Sensorama, a device created in the 1950 s to provide simulated experiences through the stimulation of the senses. Its creator, Morton L. Heilig, was convinced of the pedagogical potential of this device, which was based on the idea that a person could learn more effectively by experiencing the situation rather than by reading or hearing about it (Heilig, 1962 p. 2). In appearance, the Sensorama resembled the machines in recreational halls. It used three 35-millimeter cameras and projected the recorded images simultaneously to create the illusion of three-dimensional depth. Moreover, the device was able to reproduce wind, movement and aromas, which created an even more realistic experience.

Heilig started from the idea of "immersive vision" of the first cinematographic inventions like Grimoin-Sanson's cinéorama, 20th Century Fox's cinemascope, Walt Disney's Circarama and the Soviet circular Kinopanorama (Gubern, 1969:75-76). However, he went beyond and created an experience that cannot only be seen, but can also be felt by stimulation of hearing, smell and touch, retaking to some extent the idea of pioneering inventions from the 1950s, such as Lube's Smell-O-Vision and Castle's Percepto!. What Heilig proposed in the 1960s was a fully immersive experience, which was ahead of what the new VR systems of the $21^{\text {st }}$ century offer. However, Heilig did not manage to get funding to shoot new films to test his invention, so he only filmed a motorcycle ride through the streets of Brooklyn. Thus, the Sensorama only became an anecdotal experiment in the history of the origins of VR (Rheingold, 1994; López, 2008).

In 1960, prior to the Sensorama, Heilig patented another device, the "Telesphere Mask", a head-mounted digital display that provided stereoscopic television (Rheingold, 1994 p. 64). This first head-mounted device did not evolve from its prototype form, so it is widely considered that the first VR headset display system is the one created in 1968 by Ivan Sutherland, the "Sword of Damocles". In 1965, Sutherland established the bases of a multi-sensory system which he called The Ultimate Display, a new peripheral device capable of turning a computer into "the wonderland into which Alice walked" 
(Sutherland, 1965:508). Sutherland used Carroll's novel to refer to the possibility of placing users within computer-generated graphic simulations, in short, to walk into wonderland like Alice did, but in this case through a display designed for that purpose. Three years later, he made it happen with the creation of his VR headset. The "Sword of Damocles" consisted of a mechanical arm that was suspended from the ceiling and held a visualisation system formed by two small screens that were mounted on the user's head. This helmet allowed the user to see the three-dimensional images generated by the computer and detected the position and orientation of the user's head through the use of sensors; although it only reproduced polygons and its graphical capacity was very limited (Sutherland, 1968; Levis, 2006).

In this second stage, it is worth mentioning Myron Krueger, who in 1975 created the "Videoplace", a system that captured the user's silhouette with a video camera. A computer processed the image to place it within a digital scenario and the result was projected on a screen (Krueger, Gionfriddo and Hinrichsen, 1985). Unlike Sutherland, Krueger opted not to cover the user's head with a device but to create an environment that was able to interact with the user's presence. Krueger's invention is based on a different conception of VR that leads to the concept of Augmented Reality (AR) that subsequently became a direct predecessor of what this technology became. Unlike what happens with VR, AR does not take the user to a simulated environment but adds information to the real world. In other words, in contrast to VR, AR does not block the user's view of the real world, but complements it with computer-generated data, videos, graphics, text and virtual objects (Milgram y Kishino, 1994; Milgram, Takemura, Utsumi and Kishino, 1994).

\section{From the second half of the 1970s to 1990: The impulse of VR and the boom of user detection systems}

Developments in VR took a double direction in the second half of the 1970s: on the one hand, research and development in visualisation devices went on and, on the other, the first user-detection systems began to be developed. The first data gloves emerged during this time (Sayre Glove, DataGlove and Mattel's PowerGlove) and in the 1980s new models of data gloves were brought to market, like the MIT-LED Glove, developed by the MIT Architecture Machine Group; Gary Grimes's Digital Data Entry; the Dexterous Hand Master, developed by Arthur D. Little and Sarcos; James Kramer's CyberGlove; and the Space Glove, developed by W Industries (Sturm and Zeltzer, 1994 pp. 32-34).

Continuing with the development of motion-tracking systems, in 1987 the DataSuit was introduced by VPL Research Inc. It was a full-body version of the DataGlove (Rheingold, 1994), that covered the user's body from top to bottom and was equipped with sensors for measuring the movement of arms, legs and trunk, in six degrees of freedom within the room (Lasko-Harvill, Blanchard, Smithers, Harvill and Coffma, 1988).
In 1989, VPL Research also launched the EyePhone system, which used special VR goggles and a DataGlove. Lanier also introduced the "Reality Built for Two" (or RB2), a pack containing two pairs of VPL DataGlove and two EyePhones (Blanchard et al., 1990; Diltea, 1990). This system had some limitations: it could only generate five or six frames per second and the software and computers required to run it were expensive to buy, which made the investors to lose interest (2014). At this time there were other VR headset proposals that were not successful, such as the CyberFace and the Flight Helmet released by LEEP and Virtual Research, respectively.

In the late 1980s, the first virtual worlds began to appear. As López points out (2008 p. 139), some of them were developed as an extension of chat rooms and online games. This is the case of Habitat, a massively multiplayer online role-playing game (MMORPG) created in 1986 by Lucasfilm Games, which constitutes one of the first attempts to create a large-scale, multi-user, commercial virtual environment (Morningstar and Farmer, 1991). Habitat allowed players a real-time view of a virtual world in which they could communicate and interact with other users, which is a clear predecessor of other online multiplayer games such as Second Life (Linden Research Inc., 2003). The relationship between this type of games and VR is evident, and these games might even be considered to be predecessors in some respects, although they do differ greatly from VR games available today.

\section{From 1990 to 2012: The influence of videogames on the development of $\mathrm{VR}$}

In 1992 Carolina Cruz-Neira presented the CAVE (Cave Automatic Virtual Environment) system, which is a multi-user immersion system, unlike the individual HMD systems (Cruz-Neira, Sandin, DeFanti, Kenyon and Hart, 1992:135). It is a room-sized cube where several projectors are directed to the walls, the floor and the ceiling (the number of walls can vary depending on the application) to create a three-dimensional environment. The system has been influenced by inventions applied to cinema, such as Grimoin's Cinéorama and Waller's Cinerama, which were based on the same multi-projection system.

In the 1990s, VR arrived on the Internet with the emergence of VRML (Virtual Reality Mark-up Language), a VR modelling language that was used for the creation of the first virtual worlds (López, 2008 p. 139).

This decade also witnessed the increasing representation of VR technology in film and television, reflecting a concern for the consequences of its use. Examples of films exploring VR are The Lawnmower Man (Brett Leonard, 1992) and its sequel, The Lawnmower Man II: Beyond the Cyberspace (Farhad Mann, 1996), Virtuosity (Brett Leonard, 1995), Brainscan (John Flynn, 1994), Strange Days (Kathryn Bigelow, 1995), Ghost in the Shell (Mamoru Oshii, 1995), eXistenZ (David Cronenberg, 1999), Tron (Steven Lisberger, 1982) and the Matrix trilogy (Lilly and Lana Wachowski, 1999, 2003a and 2003b). For their part, the television series that explored 
VR include the famous Star Trek: The Next Generation (Gene Roddenberry, 1987), and even Jessica Fletcher's legendary Murder, She Wrote, which in one episode features VR glasses and data gloves (A Virtual Murder, fifth episode of the tenth season, broadcast in September 1993).

The fourth stage is characterised by the arrival of consoles and computers in household and the arrival of VR in arcades. Virtuality Group launched Virtuality (Craig, Sherman and Will, 2009), which consisted of a VR helmet and a hand-held controller that allows the user to interact with the virtual world. The device had two versions: one in which the gamer stands on a kind of platform (SU), and one in which the user can sit (SD). In the field of video games for the domestic environment, companies also began to see the possibilities of VR. In 1991, Sega announced the launch of Sega VR and a VR headset for the Genesis console, but its release was cancelled. The device consisted of two LCD screens with earphones, an all-in-one head-mounted device. At the same time, Sega's HMD combined 3D images and stereo sound with a tracking system based on internal sensors that monitor the user's head movement (Della Croche et al., 2016). Following Sega's footsteps, in the late 1994, Nintendo launched Virtual Boy, a video game console with a 3D viewer mounted on a tripod, but it failed to meet sales targets and disappeared just one year after its release. The device was criticised for being uncomfortable, for its black and red graphics, and for its price tag and the limited number and variety of compatible games (Boyer, 2009; Della Croche et al., 2016).

In 1993, VectorMaxx also launched its own VR goggles, the StuntMaster VR, which had a small LCD screen for each eye and a head-motion tracking stick that was attached to the user's shoulder. Like with Nintendo's Virtual Boy, the prolonged use of StuntMaster was not advisable because it was a rather heavy unit that exerted pressure on the front of the head. In 1994, Forte Technologies launched VXF1 for PC, which again included colour LCD screens for each eye and a controller. The system became very popular because it was compatible with well-known games such as Doom (ID Software, 1993) and Descent (Parallax Software, 1995), but it was very expensive. Atari's headset, Jaguar VR, was announced in 1995 but was never launched due to the merger of Atari and JTS.

The development of domestic VR devices remained stagnant for a few years, as it was an expensive and limited-access technology (Della Croche et al., 2016). In 1994, PCVR magazine, specialised in VR, published in its January/February issue instructions for the construction of domestic movement tracking devices, for only $\$ 25$ (PCVR, 2014,). After the failures of the first home VR systems few companies were willing to bet on the development of VR consoles. However, there were new attempts in 2002, when Konami created Tobidacid Solid Eye, a folding cardboard goggle that had to be mounted by the user and could be used with PlayStation Portable; and in 2007, with the launch by VUCIX of $i$ Wear VR920 for PC, with good quality, price, lighter design, and head movement control. However, despite these inventions, between 2008 and 2011 there was a period of "silence" as far as VR development is concerned. It was not until 2012 when the development of VR devices for public consumption begin to experience a real boost.

\section{From 2012 to the present day: the boom of commercial VR visualisation devices}

In 2012 Google announced the launch of Google Glass, a wearable computer featuring AR eyeglasses capable of displaying information to the user. Google Glasses function as a hands-free smartphone that is controlled by voice commands and movements. The glasses incorporate a small screen at the top of the glass, above the natural line of sight, offering information that complements, do not changes, the reality of the user (Google developers, 2015). The device was made available to developers in 2013, while the non-specialised public version was launched in 2014. Although the device had a lot of impact and good reception by the users, the company decided to stop the production the next year. In 2012, Palmer Luckey launched a campaign in the crowdfunding platform Kickstarter to raise funds to create an HMD for public sale called Oculus Rift. The crowdfunding campaign was successful and the first version of Oculus Rift $D K 1$ went on sale in July 2014 and the second, $D K 2$, in 2015. This device introduces a motion tracking system that allows the software to respond to the user's actions. In addition, 2016 saw the launch of Oculus Touch, a pair of small controllers for Oculus Rift that facilitate navigation in virtual environments (Oculus, 2017).

Facebook's acquisition of Oculus, in March 2014, brought back the interest to VR (Parkin, 2014) and in 2015 new proposals were put forward by big companies like Sony, Samsung and Microsoft. The development of this type of devices adopts a triple dimension:

1. HMD connected to the computer, such as Oculus.

2. Devices connected to the smartphone.

3. Devices connected to video game consoles.

Other systems that combine VR with AR were also launched during this time by different tech companies, including Google Cardboard, Gear VR, HTC Vive, OSVR (Open Source Virtual Reality), ImmersiON Vrelia GO, FOVE VR, Gameface, PlayStation VR, Elf VR, HoloLens and Magic Leap.

VR is, therefore, a technology in constant evolution and growth that has managed to open a gap in the market. While in the 1990s low screen resolutions and poor graphic quality did not allow the creation of truly immersive and appealing experiences, in the new century technological improvements (in both software and hardware) experienced a significant breakthrough in the development of devices capable of producing more and more realistic experiences. It is at this time when commercial VR systems began to experience a real boom and regained the interest of the public while expanding the scope of their 
application. Proof of this is the increase in the number of active users in VR, which according to Statista (2019) went from 6.7 million users in 2015 to 171 in 2018.

\section{FUTURE PROJECTIONS AND PROSPECTS FOR VR}

In the first two decades of the $21^{\text {st }}$ century, since the earliest beginnings of VR, it has been possible to observe the emergence of numerous studies that explore its application possibilities in a wide range of disciplines. As it is a technology that evolves very quickly, the fields that can be benefited by the employment of VR also increase as they incorporate new advances and improvements in terms of interaction and visualisation systems (interfaces), and in relation to content presentation. In this sense, Sherman and Craig (2003:417) establish a classification of the "problems" whose solution can be benefited by the use of VR: those that cannot be reproduced in the physical world, those that cannot be studied safely or involve physical risks, those whose experimentation carries a high economic cost, and "what would happen if...?" kind of problems. Meanwhile, from a more specific point of view, Levis (2006) differentiates two basic categories in relation to the application of VR, separating the specialised technical fields, which require previous training to use VR and are aimed at specific users, from everyday life fields, which are aimed at the general public.

In order to highlight the importance and scope of this technology, below we present the results of the review of the scientific research carried out in the last twenty years. This review is not intended to be exhaustive, since it would be impossible to mention all the large amount of diverse studies and applications. We have selected those studies that are interesting due to their pioneering work in a given field, their specific or strategic importance or their view in relation to a particular subject.

As Levis (2006) points out, more and more sectors begin to make use of technologies related to VR, with very specific applications, especially linked to medicine, scientific simulation, culture and education. Health sciences is the area where, more often, recent research has highlighted the potential benefits of using immersive environments. These studies range from patient rehabilitation, neurorehabilitation and motor rehabilitation therapies (Adamovich et al., 2003; Bayón and Martínez, 2010; Burdea, Popescu, Hentz and Colbert, 2000; Deutsch et al., 2004; Jack et al., 2001; Holden, 2005; Holden, Dyar, Schwamm and Bizzi, 2005; Merians et al., 2002; Rizzo, Schultheis, Kerns and Mateer, 2004), to the surgical training of health professionals (Grantcharov et al., 2004; Grottke et al., 2009; Jensen et al., 2015; Lim, Burt and Rutter, 2005; Seymour et al., 2002; Sturm et al., 2008). It is also important to highlight the works on the analgesic properties of VR for the treatment of pain in patients suffering from severe burns, both in adults (Hoffman, Patterson and Carrougher, 2000; Maani et al., 2011; Sharar et al., 2016; Silva, Machado, Simões and Do Céu, 2015) and children (Das, Grimmer, Sparnol, McRaee and
Thomas, 2005; Moreno and Delgado, 2013), as well as in oncologic patients (Espinoza, Baños, García-Palacios and Botella, 2013), by providing them with a distraction environment.

In clinical psychology, there are many works on the use of VR technology for the treatment of different of anxiety and psychological disorders, especially works that delve into its use as a tool for the exposure to phobias. There are important works that have proven the effectiveness of VR in the treatment of acrophobia (Choi, Jang, Ku, Shin and Kim, 2001; Emmelkamp, Bruynzeel, Drost and Van der Mast, 2001; Emmelkamp, Krijn, Hulsbosch, De Vries and Van Der Mast, 2002; Rothbaum et al., 1995a, 1995b; North and North, 1994, 1996; North, North and Coble, 1996a), agoraphobia (North, North and Coble, 1996b), arachnophobia (Carlin, Hoffman and Weghorst, 1997; García-Palacios, Hoffman, Carlin, Furness and Botella, 2002; Hoffman, García-Palacios, Carlin and Botella, 2003), claustrophobia (Botella et al., 1998; Botella, Baños, Villa, Perpiñá and García-Palacios, 2000; Botella et al., 2002), aviophobia (Baños, Botella, Perpiñá and Quero, 2001; Botella, Osma, García-Palacios, Quero and Baños, 2004; Brinkman, Van der Mast, Sandino Gunawan and Emmelkamp, 2010; Klein, 1997; Maltby, Kirsch, Mayers and Allen, 2002; Mühlberger, Wiedemann and Pauli, 2003; North, North and Coble, 1997a, 1997b; Rothbaum, Hodges, Anderson, Price and Smith, 2002; Rothbaum, Hodges, Smith, Lee and Price, 2000; Wiederhold, 1999; Wiederhold, Gervitz and Wiederhold, 1998), vehophobia (Wald \& Taylor, 2000; Wald \& Taylor, 2003; Walshe, Lewis, Kim, O’Sullivan and Wiederhold, 2003) and clossophobia (Anderson, Rothbaum and Hodges, 2003; Harris Kemmerling and North, 2002; Pertaub, Slater and Baker, 2002; Slater, Pertaud and Steed, 1999). Also frequent are the studies of the application of VR in the treatment of social anxiety (García-García, Rosa-Alcázar, Olivares-Olivares, 2011; Klinger et al., 2005; Roy et al., 2003), dissociations of the body image in eating disorders (Gómez et al., 2013; Myers Swan-Kremeier, Wonderlich, Lancaster and Mitchell, 2004; Perpiñá, Botella and Baths, 2003; Perpiñá et al., 2009; Riva Bacchetta, Baruffi and Molinari, 2002; Riva Bacchetta, Cesa, Conti and Molinari, 2004; Riva, Melis and Bolzoni, 1997), addiction to certain substances (Bordnick et al., 2004; García-Rodríguez, Pericot-Valverde, Gutiérrez and Ferrer, 2009; Kuntze et al., 2001; Lee et al., 2003; Nemire, Beil and Swan, 1999) and compulsive gambling (Botella, 2004).

Another area in which numerous research works are being carried out is the didactic possibilities of VR and the development of immersive learning environments (Bell and Fogler, 1995; Chen, 2006; De Antonio, Villalobos and Luna, 2000; Pantelidis, 2010; Pstoka, 1995; Thorsteinsson, 2013; Velev and Zlateva, 2017; Vera, Ortega and Burgos, 2003; Zapatero, 2011). In this sense, there are outstanding specialised applications, such as Construct $3 D$, developed by Kaufmann, Schmalstieg and Wagner (2000) for the learning of mathematics and geometry in secondary and university education levels, and 
the doctoral thesis written by Daniel Zapatero (2007), which analyses the didactic applications of VR in the Pedagogical Museum of Children's Art (MuPAI) of the Complutense University of Madrid. Also, within the educational context, several studies have been carried out on the use of this technology in the detection of problems in the school environment, such as attention deficit (Gutiérrez-Maldonado, Alsina-Jurnet, Carvallo-Becíu, LetosaPorta and Magallón-Neri, 2007; Moreno, Espinosa, Camacho and Díaz, 2016). At the same time, and continuing with the pedagogical approach, but, in this case, oriented towards the museum and public spaces, different authors have observed the benefits of VR in this context (Gurri and Carreras, 2003; Hirose, 2005; Otero and Flores, 2011; Ortiz and Cipagauta, 2006; Roussou, 2001; Wojciechowski, Walczak, White and Cellary, 2004). Moreover, some centres have already developed their own apps, like the National Archaeological Museum (Vivir en..., 2017), which offers a "trip to the past" and offer a virtual journey through the history of Spain, and the Louvre, which offers a VR experience developed by You Visit, which allows the user to explore the different rooms of the museum. Moreover, VR is used in other cultural areas such as historical heritage (Gutiérrez and Hernández, 2003; Pletinckx, Callebaut, Killebrew and Silberman, 2000), tourism (Guttentag, 2010; Potter, Cartes and Coghlan, 2016), plastic arts (Simó, 2001, 2012) and even library science. In the latter case, it is of particular interest the research carried out by Hilera, Otón, Martínez and García (2000) on the creation of VR libraries that provide access to digital books.

Different studies highlight the similarities between VR and the performing arts. Suffices to mention the first use of the term by Artaud in Le Théâtre et son doublé (1938) and Heilig in Theatre of Experience (1955). For Reaney (1996), theatre as VR allows audiences to "visit imaginary worlds that are interactive and immersive" (Reaney, 1996, p. 28). Dixon (2006), for his part, believes that VR technology enriches the theatrical experience. For this author, the combination of VR and theatre and other performing arts constitutes a perfect union as it offers an ideal technological medium to improve the theatrical experience: "visual spectacle, imaginary worlds, innovative spaces and, most importantly, audience immersion" (Dixon, 2006:23). Other authors have also focused their studies on the possibilities of VR in theatre, dance and music. In this sense, it is worth mentioning the work of Yang, Leung, Yue and Deng (2012) and Chan, Leung, Tang and Komura (2010) on the creation of dance training systems based on VR technology. There are other significant projects aimed at the non-specialised public, such as Night Fall (2016), the first ballet piece in 360-degree video developed by the Dutch National Opera and Ballet; Scene 360, an app for mobile devices launched by La Cocina project (2016), of RTVE.es, and La Sala show, produced by Radio Nacional of Spain in collaboration with the Dramatic Nacional Centre (CDN) and the National Institute of Performing Arts and Music (INAEM), a theatrical project in 360-degree video format that offers new content such as Alento 360 (classical dance) and Misántropo 360 (another theatrical piece); and the VR concerts performed by the Adelaide Symphony Orchestra (Australia) in 2015, in collaboration with Jumpgate VR. It should be noted, in the case of music, the creation of the Lyra VR app (2017), a platform to create music compositions in a VR environment.

The multiple possibilities of VR are also explored in studies related to architecture and urbanism (Nguyen, Nguyen, Vo, Nguyen and Tran, 2016; Villegas, 2012); astronomy (Mintz, Litvak and Yair, 2001; Weigel and Moraitis, 2017) -NASA has also been using VR for astronaut training for several years and has collaborated in the creation of different immersive pieces that allow the general public to explore the International Space Station (in Mission ISS, 2017) and the surface of Mars (NASA Mars Cardboard Experience, 2017)-; law, in relation to the challenges of the regulations of this technology (Carreño, 2012; Lemley and Volokh, 2017); engineering, applied to the teaching of students (Flores, Camarena and Avalos, 2014); zoology, to investigate animal behaviour in simulated environments (Dolins, Schweller and Milne, 2017; Thurley and Ayaz, 2016); military training (Bhagat, Liou and Chang, 2016; Pallavicini, Argenton, Toniazzi, Aceti and Mantovani, 2016), vehicle and machinery operation simulation (Ihemedu-Steinke, Sirim, Erbach, Halady and Meixner, 2015; Ong and Nee, 2004; Tudor, Carey and Dubey, 2015) and marketing and corporate advertising (Scatena, Russo and Riva, 2016; Yol and Shin, 2009) and institutional advertising, with outstanding campaigns like You choose (2017) of the Directorate General of Traffic (DGT), which uses VR to raise awareness about the risks of irresponsible driving behaviour, and Keep it between us (2017), a project developed by Uruguay's Council of Secondary Education to raise awareness about teen dating violence.

\section{An approach to VR entertainment}

As it has been shown in this study, the emergence of VR has been strongly linked to entertainment, so it is not surprising that this technology has been greatly exploited in this field. According to Levis's classification (2006), the use of VR in the entertainment industry reaches very different fields such as cinema, television, social networks and video games, and has become the first access route to this technology for the non-specialised public. This new reality has given rise to a series of interactive narratives that are characterised for being produced in VR environments, which allows us to talk about a type of virtual and interactive leisure.

In cinema there are both small immersive experiences that act as promotional material that persuades the audience to go to the movie theatre, and works that delve into narrative film production supported by HMD and VR cinema technology (Cortés-Selva, 2015, 2016; Martínez, 2015). Examples of feature films made to be viewed with VR goggles include Jesus VR: The Story of Christ (2016), which is the first production to use this immersive technology in cinema; and Carne y Arena (2017), which presents the real-life stories of immigrants and refugees in 
VR. Moreover, in recent years there has been a proliferation of companies and applications dedicated exclusively to VR cinema, such as the CINEVR-The Movie Theater app (2018). On the other hand, for the public who still prefers to go to the movie theatre, the first VR cinema was inaugurated in Amsterdam in early 2016, and soon after a similar cinema opened its doors in India. In Los Angeles, the IMAX Corporation has developed its own VR cinema. In these cases, the seats are accompanied by a pair of VR goggles and the spectator can select from a catalogue of movies. Finally, since 2014 there are companies dedicated to the production of VR films, like Oculus Story Studio and The VR Company.

Regarding fiction television, there is an increasing number of series that use VR technology, both new series that were conceived as VR products since their conception (native VR series), such as Invisible (Samsung, JAUNT, CNÉ and 30 Ninjas) and Halcyon (Syfy), as well as consolidated series that decided to integrate immersive to attract new viewers (Paíno and Rodríguez, 2017). Examples include Game of Thrones (HBO), which has two VR pieces, Ascend the Wall (for Oculus Rift) and Defend the Wall (for HTC); The Simpsons (FOX), with its Planet of the Couches; Sleepy Hollow (FOX), with its Sleepy Hollow VR experience; the Spanish series El Ministro del Tiempo (RTVE) and its VR spin-off El tiempo en tus manos ("The time in your hands"); and The Walking Dead (AMC) and Stranger Things (Netflix).

Another area of application for VR is social networks. First, Facebook implemented 360-degree videos in December 2016 (Facebook Live 360) and launched the Beta version of its VR social network Facebook Spaces in April 2017. Moreover, the vTime and BeanVR apps were also released also at the beginning of 2017. In all these examples the user can create a customisable digital avatar that will appear in the chosen meeting room or space to interact with his friends' avatars.

Lastly, in relation to VR video games, they are one of the main ways for the public to access this technology since VR video game development companies are the ones betting stronger in the creation of contents for VR devices oriented to the general public. Thus, there are many companies dedicated to the development of VR games for specific HMD, like Oculus Rift, PlayStation VR, HTC Vive and OSVR, but there are other companies that also develop content that can be viewed in smartphones paired with low-cost VR goggles (cardboard type). Within this context of entertainment there are outstanding projects such as Hellblade: Senua's Sacrifice (2017), a dark fantasy action-adventure video game that deals with mental illnesses and has been developed by Ninja Theory with the collaboration of researchers specialised in neuroscience.

\section{CONCLUSIONS}

Taking into account the aspects discussed above, it can be concluded that in order to understand how VR works and all the possibilities it offers, it is necessary not only to take into account the different technological innovations of recent years but also the origins of the cinematographer, in which the idea of going beyond the limits of reality imposed by the technology of that time was already present. What seemed to be science fiction, today has become a reality, and proof of this are the different contexts where VR is already being applied, as this study has shown.

In relation to the term VR, it was initially linked to literature and, more specifically to the science fiction genre, where some authors began to talk about what is currently known to be the essence of VR: immersion. In short, one could say that the term was born linked to a narrative context, independently of the technological advances. The clearest example is the sequence in Alice in Wonderland where the protagonist's sister enters the same world that Alice just left. The development of the digital context is what allowed overcoming the narrative-conceptual plane and what gave way to the definition of what we currently understand as VR and which, unlike previous times, is now associated to a series of components (VR goggles, haptic devices, 360-degree video content) that enable user's real-time immersion.

The past and present of VR allows us to speak of five great stages that are linked to technological variables, which in turn involve a series of intrinsic social variables that derive from the historical context in which they are framed and are essential to understand this evolution. These stages are characterised by the following issues:

1. From 1833 to 1950 : There are inventions that can be considered remote predecessors of the first VR viewers related to the first theories of vision. The most important figures are Charles Wheatstone, Wilhelm Rollmann, Louis Ducos du Hauron and Hugo Gernsback.

2. From 1950-60 to the first half of the 1970s: The first virtual reality HMD emerge, strongly linked to the military field and simulations. In this period, names such as Morton Heilig, Ivan Sutherland and Miron Krueger stand out.

3. From the second half of the 1970s to 1990: VR and user detection systems experience a boom. Visualisation devices continue to improve, and a second line of research on the detection of user's movement within the virtual world starts to develop.

4. From 1990 to 2012: It is a stage marked by the release of films that begin to explore virtual worlds and the development of computer VR games. The Cave Automatic Virtual Environment (CAVE) system also emerges during this stage at the hands of Carolina Cruz-Neira.

5. From 2012 to the present day: The Oculus Rift VR headset is released, and the first HMD systems begin to reach the non-specialised public. Especially from 2014 onwards, companies specialised in VR proliferate and revenues in the sector multiply.

As shown in the last part of this study, the interest in VR has been increasing. There are more and more areas 
of knowledge that have benefited, to a greater or lesser extent, by the application of this technology and the haptic and visualisation devices that depend on it. It is precisely in this plane where we can see that truth is better than fiction and that it has been reflected in the different areas where VR is currently used: education, medicine, journalism, engineering, psychology, among others. In this sense, it is possible to argue that VR is reaching a consolidation phase, in such a way that it has managed to overcome its perception as a "fad" and to make an important gap in the technological market and in the entertainment industry. In short, all these research works demonstrate the wide spectrum of possibilities that VR encompasses, which adapts to the specific needs of each knowledge area, making the study of this technology increasingly complex.

All these aspects that have been discussed above constitute a starting point for VR as an object of study, which in this case is understood from other perspectives that have not been addressed in this work, such as: user's narrative immersion and everything related do the accelerated progress this technology is experiencing in the digital context.

\section{REFERENCES}

Adamovich, Sergei, Merians, A. S., Boian, Rares Florin and Tremaine, Marilyn (2003) "A virtual reality based exercise system for hand rehabilitation post-stroke". Proceedings of the Second International Workshop on Virtual Rehabilitation. pp. 74-81. doi: 10.1109/IEMBS.2004.1404364

Anderson, Page; Rothbaum, Barbara O. and Hodges, Larry (2003) "Virtual reality exposure in the treatment of social anxiety". Cognitive and Behavioral Practice. 10 pp. 240-247. doi: 10.1016/ S1077-7229(03)80036-6

Artaud, Antonin (1978) El teatro y su doble. Barcelona, Spain: Edhasa.

Baños, Rosa, Botella, Cristina, Perpiñá, Conxa and Quero, Soledad (2001) "Tratamiento mediante realidad virtual para la fobia a volar: un estudio de caso" Clínica y Salud. 12(3) pp. 391-404. https://goo.gl/fCEeb2 [Accessed 20 January 2019]

Barthes, Roland (1990) La cámara lúcida. Barcelona: Paidós.

Bayón, Manuel and Martínez, J. (2010) "Rehabilitación del ictus mediante realidad virtual". Rehabilitación. 44(3) pp. 256-60. doi: 10.1016/j.rh.2009.11.005

Bell, John T. and Fogler, H. Scott (1995) "The investigation and application of Virtual Reality as an educational tool". Proceedings of the American Society for Engineering Education Annual Conference, Session 2513. California. https://goo.gl/JymA2V [Accessed 20 January 2019]

Bhagat, Kaushai Kumar; Liou, Wei-Kai and Chang, Chun-Yen (2016) "A cost-effective interactive 3D virtual reality system applied to military live firing training". Virtual Reality. 20 pp. 127-140. doi: 10.1007/s10055-016-0284-x

Biocca, Frank and Levy, Mary (1995) Communication in the Age of Virtual Reality. New Jersey, Lawrence Erlbaum Associates.

Blanchard, Chuck, Burgess, Scott, Havill, Young, Lanier, Jaron, Lasko, Ann, Oberman, Mark and. Teitel, Mike (1990) "Reality built for two: a virtual reality tool". Proceedings of the 1990 symposium on Interactive $3 D$ graphics. pp. 35-36. doi: 10.1145/91385.91409

Bordnick, Patrick S., Graap, Ken M., Copp, Hilary, Brooks, Jeremy, Ferrer, Mirtha and Logue, Bobby (2004) "Utilizing virtual reality to standardize nicotine craving research: A pilot study". Addictive Behaviors, 29 pp, 1889-1894.

Botella, Cristina (November 2004) A Virtual environment for the treatment of pathological gambling. Communication delivered on the 38th Annual AABT Convention, New Orleans.
Botella, Cristina, Baños, Rosa, Perpiñá, Conxa, Villa, Helena, Alcañiz, M. and Rey, A. (1998) "Virtual reality treatment of claustrophobia: A case report". Behaviour Research and Therapy. 36 pp. 239-246. https://goo.gl/2dhFkW [Accessed 20 January 2019]

Botella, Cristina, Baños, Rosa, Perpiñá, Conxa and Villa, Helena (2000) "Virtual reality in the treatment of claustrophobic fear: A controlled, multiple-baseline design". Behaviour Therapy. 31 pp. 583-595. https://goo.gl/rshMJ4 [Accessed 20 January 2019]

Botella, Cristina, Baños, Rosa, Perpiñá, Conxa and Quero, Soledad (2002) "El tratamiento de la claustrofobia por medio de realidad virtual". Análisis y Modificación de Conducta, 28(117) pp. 109-127. Retrieved from https://goo.gl/H8DxQ7 [Accessed 17 May 2017.

Botella, Cristina, Osma, Jorge, García-Palacios, Azucena adn Quero, Soledad (2004) "Treatment of flying phobia using virtual reality: Data from a 1-year follow-up using a multiple baseline design". Clinical Psychology and Psychotherapy. 11 pp. 311323. doi: $10.1002 /$ cpp.404

Botella, Cristina, García-Palacios, Azucena, Baños, Rosa and Quero, Soledad (2007) "Realidad virtual y tratamientos psicológicos". Cuadernos de medicina psicosomática y psiquiatría de enlace, 82 pp. 17-31. https://goo.gl/biKAzr [Accessed 20 January 2019]

Boyer, Steven (2009) "A Virtual Failure: Evaluating the Success of Nintendo's Virtual Boy”. The Velvet Light Trap. 64 pp. 23-33.

Brinkman, Willem-Paul, Van der Mast, Charles, Sandino, Guntur, Gunawan, Lucy T. and Emmelkamp,Paul M.G. (2010) "The therapist user interface of a virtual reality exposure therapy system in the treatment of fear of flying". Interact Comput. 22(4) pp. 299-310. doi: 10.1016/j.intcom.2010.03.005

Burdea, Grigori et al. (2000) "Virtual reality-based orthopedic telerehabilitation". IEEE Transactions on Rehabilitation Engineering, 8(3): 430-432. doi: 10.1109/86.867886

Cabezos, Pedro Manuel (2014) Imágenes estereoscópicas aplicadas a la representación arquitectónica $(\mathrm{PhD}$ thesis, Universitat Politécnica de Valencia). https://goo.gl/Joc4SJ [Accessed 20 January 2019]

Carlin, Albert, Hoffman, Hunter G. and Weghorst, Suzanne (1997) "Virtual reality and tactile augmentation in the treatment of spider phobia: a case report". Behaviour Research and Therapy, 35(2) pp. 153-158. doi: 10.1016/S0005-7967(96)00085-X

Carreño, Dalia (2012) "El derecho en la era de la virtualidad. Nuevas realidades, nuevo derecho virtual". Ara Boni et Aequi, 8 (2), 251-273. https://goo.gl/KViqxa [Accessed 20 January 2019]

Chan, Jacky C.P., Leung, Howard, Tang, Jeff K.T. and Komura, Taku (2010) "A Virtual Reality Dance Training System Using Motion Capture Technology". IEEE Transactions on Learning Technologies. 4(2) pp. 187-195. doi: 10.1109/TLT.2010.27

Chen, Chwen Jen (2006) "The design, development and evaluation of a virtual reality based learning environment". Australasian Journal of Educational Technology. 22(1) pp. 39-63. doi: 10.14742/ ajet.1306

Choi, Young H., Jang, Dong P., Ku, Jeong H.. Shin, Min B. and Kim, Sun I. (2001) "Short-term treatment of acrophobia with virtual reality therapy (VRT): A case report". CyberPsychology \& Behavior, 4 pp. 349-354. doi: 10.1089/109493101300210240

Coates, George (1992) Invisible Site: a virtual sho. A multimedia performance work. San Francisco, Works.

Cook Myers, Tricia, Swan-Kremeier, Lorraine, Wonderlich, Stephen, Lancaster, Kathy and Mitchell, James E. (2004) "The use of alternative delivery systems and new technologies in the treatment of patients with eating disorders". International Journal of Eating Disorders. 36 pp. 123-143. doi: 10.1002/eat.20032

Cortés-Selva, Laura (2015) "Viaje al centro de la inmersión cinematográfica: del cine primitivo al VRCinema”. Opción. 31(4) pp. 352-371

Cortés-Selva, Laura. (2016) "En busca del VRCinema. Del cine proto-inmersivo al cine inmersivo". Discursos fotográficos, 12(20) pp. 173-204.

Craig, Alan, Sherman, William and Will, Jeffrey (2009) Developing Virtual Reality Applications. Burlington, Morgan Kaufmann. 
Crone, Robert (1992) "The history of stereoscopy". Documenta Ophthalmologica. 81 pp. 1-16. doi: 10.1007/BF00155009

Crowter, Bosley (1959) Smells of China; 'Behind Great Wall' Uses AromaRama. The New York Times. https://goo.gl/AgdbmG [Accessed 20 January 2019]

Cruz-Neira, Carolina, Sandin, Daniel J., DeFanti, Thomas Albert, Kenyon, Robert V. and C. Hart, John (1992) "The Cave: Audio Visual Experience Automatic Virtual Environment". Communications of the ACM. 35(6) pp, 65-72. doi: 10.1145/129888.129892.

Das, Debashish A., Grimmer, Karen A ., Sparnon, Anthony L., McRae, Sarah E. and Thomas, Bruce H (2005) "The efficacy of playing a virtual reality game in modulating pain for children with acute burn injuries: a randomised controlled trial". $B M C$ Pediatrics, 5(1). doi: 10.1186/1471-2431-5-1

David, Jack, Rares, Boian, Merians, Alma S., Tremaine, Marilyn, Burdea, Grigore C., Adamovich, Sergei V., Recce, Michael and Poizner, Howard (2001) "Virtual reality-enhanced stroke rehabilitation". IEEE Transactions on Neural Systems and Rehabilitation Engineering, 9(3) pp. 308-318. doi: 10.1109/7333.948460

De Antonio, Angelica, Villalobos, Marco and Luna, Enrique (2000) "Cuándo y cómo usar la realidad virtual en enseñanza". Enseñanza y Tecnologia, January-abril pp. 26-36. https://goo.gl/Wtd$\mathrm{kcL}$ [Accessed 20 January 2019]

Della Croche, Leadro (2016) "Realidade virtual - A viabilidade da imersão total na atualidade". Revista Contribuciones a las Ciencias Sociales, July-Sept.

Del Pino, Luis (1995) Realidad virtual. Madrid, Spain, Paraninfo.

Deutsch, Judith E., Paserchia, C., Veccione, C, and Mirelman, Anat. (2004) "Improved gait and elevation speed of individuals poststroke after lower extremity training in virtual environments". Journal of Neurologic Physical Therapy, 28(4) pp. 185-186. https://goo.gl/bgbsdE [Accessed 20 January 2019]

Diltea, Steve (August 1990) Grand Illusion. Coming soon, to your home... Artificial Reality. New York, pp. 26-34. https://goo.gl/ zOGa2X [Accessed 20 January 2019]

Dixon, Steve (2006) "A history of virtual reality in performance". International Journal of Performance Arts and Digital Media, 2(1) pp. 23-54.

Dolins, Francine L., Schweller, Kenneth and Milne, Scott (2017) "Technology advancing the study of animal cognition: using virtual reality to present virtually simulated environments to investigate nonhuman primate spatial cognition". Current Zoology, 63(1) pp. 97-108. doi: 10.1093/cz/zow121

Eder, José María (1978) History of Photography. New York, Dover Publications.

Ekweariri, Chidiewere S. (2013) "Synthetic design and the art of virtual reality in theatre and film productions". EJOTMAS: Ekpoma Journal of Theatre and Media Arts, 4(1-2). https://goo.g1/ NdDpdQ [Accessed 20 January 2019]

Emmelkamp, P. M., Bruynzeel, M., Drost, L. and Van der Mast, C. A. (2001) Virtual reality treatment in acrophobia: a comparison with exposure in vivo. Cyberpsychol Behaviour, 4(3), 335-339. doi: 10.1089/109493101300210222

Emmelkamp, Paul M. G., Krijn, M., Hulsbosch, L., De Vries, S., Schuemie, M. .J. and Van der Mast, C. A. P. G. (2002) "Virtual reality treatment versus exposure in vivo: a comparative evaluation in acrophobia". Behaviour Research and Therapy, 40(5) pp. 509-519. doi: 10.1016/S0005-7967(01)00023-7

Espinoza, Macarena, Baños, Rosa M., García-Palacios, Azucena and Botella, Cristina (2013) La realidad virtual en las intervencions psicológicas con pacientes oncológicos. Psicooncología, 10(23) pp. 247-261. doi: 10.5209/rev_PSIC.2013.v10.n2-3.43447

Fernández-Sora, Alberto (2011) Dyna, 78(167) pp, 7-16. https:// goo.gl/aZDCvr [Accessed 20 January 2019]

Flores, Jesús Alberto, Camarena, Patricia and Avalos, Elvira (2014) "La Realidad Virtual una Tecnología Innovadora Aplicable al Proceso de Enseñanza de los Estudiantes de Ingeniería". $A p$ ertura: Revista de Innovación Educativa, 6(2) pp. 86-99. https://goo.gl/glt09g [Accessed 20 January 2019]

Fraga, Fernando (2013) La captación de la imagen en la pintura de Caravaggio ( $\mathrm{PhD}$ thesis, Universidade da Coruña). https://goo. gl/BFMS2q [Accessed 20 January 2019]
García-García, Emilio S., Rosa-Alcázar, Ana I. and Olivares-Olivares, Pedro J. (2011) “Terapia de exposición mediante realidad virtual e Internet en el Trastorno de Ansiedad/Fobia Social: una revisión cualitativa". Terapia psicológica, 29(2) pp. 233-243. doi: 10.4067/S0718-48082011000200010

García-Palacios, Azucena, Hoffman, Hunter, Carlin, Albert, Furness, Thomas, A, and Botella, Cristina (2002) "Virtual reality in the treatment of spider phobia: a controlled study". Behaviour Research and Therapy, 40 pp. 983-993. doi: 10.1016/S00057967(01)00068-7

García-Rodríguez, Olaya, Pericot-Valverde, Irene, Gutiérrez Maldonado, José and Ferrer García, Marta (2009) "La realidad virtual como estrategia para la mejora de los tratamientos del tabaquismo". Health and Addictions, 9(1) pp. 39-55. https:// goo.gl/By5KTq [Accessed 20 January 2019]

Gómez Péresmitré, Gilda, León Hernández, Rodrigo, Platas Acevedo, Silvia, Lechuga Hernández, Mariana, Cruz, Diana and Hernández Alcántara, Alfredo (2013) "Realidad Virtual y Psicoeducación: Formatos de Prevención Selectiva en Trastornos de la Conducta Alimentaria". Revista mexicana de trastornos alimentarios, 9(1) pp. 39-55. https://goo.gl/tQHPaq [Accessed 20 January 2019]

González, Laura (2005) Fotografia y pintura: ¿dos medios diferentes? Barcelona, Editorial Gustavo Gili.

Google Developers (2015) Guía de usuario de Google Glass. https://goo.gl/ZczE04 [Accessed 20 January 2019]

Grantcharov, Teodor P. (2004) "Randomized clinical trial of virtual reality simulation for laparoscopic skills training". British Journal of Surgery, 91(2) pp. 146-150. doi: 10.1002/bjs.4407

Greenbaum, P. (1992) The lawnmower man. Film and video, 9(3): 58-62.

Grottke, Oliver, Ullrich, Sebastian, Ntouba, Alexandre and Liao, Wei (2009) "Virtual reality-based simulator for training in regional anaesthesia". British Journal of Anaesthesia, 103(4) pp. 594-600. doi: 10.1093/bja/aep224

Gubern, Román (1969) Historia del cine. Barcelona, Lumen.

Gubern, Román (1996) Del bisonte a la realidad virtual: la escena y el laberinto. Barcelona, Anagrama.

Gurri, Josep and Carreras, César (2003) Realidad virtual en nuestros museos: experiencias de la colaboración entre Dortoka y el grupo Oliba. IN3: UOC. (Working Paper Series; WP03-004). https://goo.gl/Vgwwmq [Accessed 20 January 2019]

Gutiérrez, Diego and Hernández, Luis A. (2003) "Potencial de la Realidad Virtual en el ámbito del patrimonio". Revista PH, 46. https://goo.gl/4QdVUH [Accessed 20 January 2019]

Gutiérrez-Maldonado, José, Alsina Jurnet, Ivan, Carvallo Becíu, C., Letosa, Alex and Magallón-Neri, Ernesto (2007) "Aplicaciones clínicas de la realidad virtual en el ámbito escolar". Cuadernos de Medicina Psicosomática y Psiquiatría de Enlace, 82 pp. 3251. https://goo.gl/XtCDWb [Accessed 20 January 2019]

Guttentag, Daniel A. (2010) "Virtual reality: Applications and implications for tourism". Tourism Management, 31(5) pp. 637651. doi: 10.1016/j.tourman.2009.07.003

Hayes, John (2014) "You see them WITH glasses!”... A Short History of 3D Movies. Widescreen Movies Magazine. https://goo. g1/HEc0GR [Accessed 20 January 2019]

Harris, Sandra H., Kemmerling, Robert L. and North, Max (2002) Brief virtual reality therapy for public speaking anxiety. CyberPsycholoy \& Behavior, 5 pp. 543-550. doi: 10.1089/109493102321018187

Heilig, M. (1962) Patente 3,050,870, Sensorama simulator. https:// goo.gl/GuWpWZ [Accessed 20 January 2019]

Heim, Michael (1993) The Metaphysics of Virtual Reality. New York, Oxford University Press.

Hilera, José R., Otón, Salvador, Martinez, Javier and García Barriocanal, Elena (2000) Interfaces de Realidad Virtual en Bibliotecas Digitales. Paper delivered on I Jornadas de Bibliotecas Digitales, Valladolid. https://goo.gl/6Sp8f1 [Accessed 20 January 2019]

Hirose, Michitaka (2005) "Virtual Reality Technology and Museum Exhibit”. In G. Subsol (Ed.), Virtual Storytelling. Using Virtual Reality Technologies for Storytelling pp. 3-11. Berlin, Springer.

Hoffman, Hunter, García-Palacios, Azucena and Carlin, Albert (2003) "Interfaces that heal: coupling real and virtual objects to treat spi- 
der phobia". International Journal of Human-Computer Interaction, 16 pp. 283-300. doi: 10.1207/S15327590IJHC1602_08

Hoffman, Hunter G., Patterson, David R. and Carrougher, Gretchen J. (2000) "Use of Virtual Reality for Adjunctive Treatment of Adult Burn Pain During Physical Therapy: A Controlled Study". Clinical Journal of Pain, 16(3) pp. 244250. doi: 10.1097/00002508-200009000-00010

Holden, Maureen K. (2005) "Virtual environments for motor rehabilitation: Review". Cyberpsychology Behavior, 8(3) pp. 187211. doi: $10.1089 / \mathrm{cpb} .2005 .8 .187$

Holden, Maureen K., Dyar, Thomas A., Schwamm, Lee and Bizzi, Emilio (2005) "Virtual-environment based telehabilitation in patients with stroke". Presence: Teleoperators and Virtual Environments, 14(2) pp. 214-233. doi: 10.1162/1054746053967058

Howard, Ian P, and Rogers, Brian J. (1995) Binocular Vision and Stereopsis. New York, Oxford University Press.

Ihemedu-Steinke, Quinate Chioma, Sirim, DemeErbacht, Rainer and Halady, Prashanth (2015) "Development and Evaluation of a Virtual Reality Driving Simulator". In A. Weisbecker, M. Burmester \& A. Schmidt (Eds.) Mensch und Computer pp. 491498- Stuttgart, Oldenbourg Wissenschaftsverlag.

Jensen, Katrine, Bjerrum, Flemming, Jessen Hansen, Henrik, Horsleben Petersen, René, Holst Pedersen, Jesper and Konge, Lars (2015) "A new possibility in thoracoscopic virtual reality simulation training: development and testing of a novel virtual reality simulator for video-assisted thoracoscopic surgery lobectomy". Interactive Cardiovascular and Thoracic Surgery, 21(4) pp. 420-426. doi: 10.1093/icvts/ivv183

Kaufmann, Hannes, Schmalstieg, Dieter and Wagner, Michael (2000) "Construct3D: A Virtual Reality Application for Mathematics and Geometry Education". Education and Information Technologies, 5(4) pp. 263-276.

Klein, Richard (1997) "Treating fear of flying with virtual reality exposure therapy". In Vandecreek, L., \& Jackson, T. L. (Eds), Innovations in clinical practice: A source book. Florida, USA: Professional Resource Press.17 pp.449 465.

Klinger, Evelyne, Bouchard, Stéphane, Légeron, P. and Roy, S. (2005) "Virtual reality therapy versus cognitive behaviour therapy for social phobia: A preliminary controlled study". $C y$ berPsychology and Behavior, 8 76-88.

Krueger, Myron, Gionfriddo, Thomas and Hinrichsen, Katrin (1985) "VIDEOPLACE — an artificial reality". Proceedings of the SIGCHI Conference on Human Factors in Computing Systems. pp. 35-40. doi: 10.1145/317456.317463.

Kuntze, Marcus F., Stoermer, Robert, Mager, Ralph, Roessler, Andreas, Mueller-Spahn, Franz and Bullinger, Alex H. (2001) "Immersive virtual environments in cue exposure". Cyberpsychology \& Behavior, 4 pp. 497-501. doi: 10.1089/ 109493101750527051

La Ferla, Jorge (2009) Cine (y) digital: aproximaciones a posibles convergencias entre el cinematógrafo y la computadora. Buenos Aires, Ediciones Manantial.

Lanier, Jaron (1989) "An interview with Jaron Lanier". Whole Earth Review. pp. 109-118. https://goo.gl/tX80kn [Accessed 20 January 2019]

Lasko-Harvill, A., Blanchard, C., Smithers, W., Harvill, Y. and Coffman, A. (1988) "From DataGlove to DataSuit. Compcon Spring '88'. Thirty-Third IEEE Computer Society International Conference. pp. 536-538. doi: 10.1109/CMPCON.1988.4925

Lee, Jang Han, Ku, Jeonghun, Kim, Kwanguk, Kim, Byoungnyun, Kim, In Y, Yang, Byung-Hwan, Kim, Seok Hyeon, Wiederhold, Brenda Kay, Wiederhold, Mark D., Park, Dong Woo and Kim, Sun I (2003) "Experimental application of virtual reality for nicotine craving through cue exposure". Cyberpsychology y Behavior, 6 pp. 275-280. doi: 10.1089/109493103322011560

Lemley, Mark A. and Volokh, Eugene (2017) "Law, Virtual Reality and Augmented Reality". Stanford Public Law Working Paper No. 2933867. doi: 10.2139/ssrn.2933867

Levis, D. (2006) ¿Qué es la realidad virtual? https://goo.gl/WwxAeU [Accessed 20 January 2019]

Lim, Michael W., Burt, G., \& Rutter, S. V. (2005) "Use of three-dimensional animation for regional anaesthesia teaching: applica- tion to interscalene brachial plexus blockade". British Journal of Anaesthesia, 94(3) pp, 372-377. doi: 10.1093/bja/aei060

López, C. (2008) "Breve historia de los mundos virtuales". In L. Cirlot, A. Casanovas, A.T. Estévez \& M.J. Buxó (Eds.), Arte y arquitectura digital, net.art y universos virtuales. Barcelona, Grupo de Investigación Arte, Arquitectura y Sociedad digital. pp. 135-142.

Maani, Christopher V., Hoffman, Hunter G., Fowler, Marcie, Maiers, Alan J., Gaylord, Kathryn M. and DeSocio, Peter A. (2011) "Combining Ketamine and Virtual Reality Pain Control During Severe Burn Wound Care: One Military and One Civilian Patient". Pain Medicine, 12(4)pp.673-678.doi:10.1111/j.1526-4637.2011.01091.x

Martinez, Franciso Julian (2015) Cine, videojuegos y realidad virtual: estudio y prospectiva del medio audiovisual en la era digital (PhD thesis, Universidad Miguel Hernández) https://goo.gl/ kQcMgP [Accessed 20 January 2019]

Merians, Alma S., Jack, David, Boian, Rares Florin, Tremaine, Marilyn, Burdea, Grigore, Adamovich, Sergei, Recce, Michael and Poizner, Howard (2002) "Virtual reality augmented rehabilitation for patients following stroke". Physical Therapy, 82(9) pp. 898 -915. doi: 10.1093/ptj/82.9.898

Milgram, Paul and Kishino, Fumio (1994) "A Taxonomy of Mixed Reality Visual Displays". IEICE Transactions on Information and Systems, vol. E77-D (12) pp.1321-1329. https://goo.gl/ WMSDEP [Accessed 20 January 2019]

Milgram, Paul, Takemura, Haruo, Utsumi, Akira and Kishino, Fumio (1995) "Augmented Reality: A class of displays on the reality-virtuality continuum". SPIE2351, Telemanipulator and Telepresence Technologies, 282. doi: 10.1117/12.197321

Mintz, Rachel, Litvak, Shai and Yair, Yoav (2001) "3D-Virtual Reality in Science Education: An Implication for Astronomy Teaching". Journal of Computers in Mathematics and Science Teaching, 20(3) pp. 293-305. Norfolk, Association for the Advancement of Computing in Education (AACE)

Moreno, Inmaculada and Delgado, Gracia (2013) "Programa de intervención basado en realidad virtual para quemaduras pediátricas". Anuario de Psicología Clínica y de la Salud, 9 pp. 49-51. https://goo.gl/HkJ121 [Accessed 20 January 2019]

Moreno, Inmaculada, Espinosa-Oneto, Nazaret, Camacho-Vara del Rey, Carlos and Diaz-Orueta, Unai (2016) "Evaluación del Trastorno por Déficit de Atención e Hiperactividad mediante Realidad Virtual. Comparación con escalas conductuales". Comunicación y Pedagogía, 287-288 pp. 33-38.

Morningstar, Chip and Farmer, F. Randall (1991) "The Lessons of Lucas film's Habitat". In M. Benedikt (Ed.), Cyberspace: First Steps. Cambridge, United Kingdom: MIT Press.

Mühlberger, Andreas, Wiedemann, Georg and Pauli, Pauli (2003) "Efficacy of one-session virtual reality exposure treatment for fear of flying". Psychotherapy Research, 13 pp. 323-336. doi: $10.1093 / \mathrm{ptr} / \mathrm{kpg} 030$

Nemire, Kenneth, Beil, Joshua and Swan, Ronald W. (1999) "Preventing teen smoking with virtual reality". Cyberpsychology \& Behavior, 2 pp. 35-47. doi: 10.1089/cpb.1999.2.35

Nguyen, Minh-Tu, Nguyen, Hai-Khanh, Vo-Lam, Khanh-Duy, Nguyen, Xuan-Gieng and Tran, Minh-Triet (2016) "Applying Virtual Reality in City Planning". In S. Lackey \& R. Shumaker (Eds), Virtual, Augmented and Mixed Reality. pp. 724-735. Springer. doi: 10.1007/978-3-319-39907-2 69

North, Max and North, Sarah (1994) "Virtual environments and psychological disorders". Electric Journal of Virtual Culture, 9 pp. 25-34.

North, Max and North, Sarah (1996) "Virtual reality psychotherapy". The Journal of Medicine and Virtual Reality, 1 pp. 28-32.

North, Max, North, Sarah, and Coble, Joseph (1996a) "Effectiveness of VRT for acrophobia. Virtual reality therapy". An innovate paradigm. Colorado Springs, USA: IPI Press. pp. 68-70.

North, Max, North, Sarah and Coble, Joseph (1996b) "Effectiveness of virtual environment desensitization in the treatment of agoraphobia". Presence: Teleoperators and Virtual Environments, 5 pp. 346-352. doi: 10.1162/pres.1996.5.3.346

North, Max, North, Sarah and Coble, Joseph. (1997a) "Virtual reality therapy for fear of flying". American Journal of Psychiatry, $154(1)$ 
North, Max, North, Sarah and Coble, Joseph (1997b) Virtual reality therapy. Michigan, USA: I. P. I. Press.

Novak, Matt (2012) Telemedicine Predicted in 1925. smithsonian. com. https://goo.gl/vpeMOU [Accessed 20 January 2019]

Oculus (2017) Oculus. https://goo.gl/9s1dQo [Accessed 20 January 2019]

Ong, S. K. and Nee, Andrew Y. C. (2004) Virtual and Augmented Reality Applications in Manufacturing. London, Springer.

O'Neill, Paul (1963) "Barnum of the space. The amazing Hugo Gernsback, prophet of science". Life. pp. 62-68. https://goo.gl/ R8FsSG [Accessed 20 January 2019]

Ortiz, Jorge Eduardo and Cipagauta, Rodolfo (2006) "Un Museo Virtual de Arte". Ingeniería e Investigación, 26(3) pp. 78-84. https://goo.gl/EDf2J2 [Accessed 20 January 2019]

Otero, Antonio and Flores, Julian (2011) "Realidad Virtual como medio de comunicación de contenidos. Aplicación como herramienta educativa y factores de diseño e implantación en museos y espacios públicos". Icono14, 9(2) pp. 185-211. doi: 10.7195/ri14.v9i2.28

Paíno, Adriana and Rodríguez, María Isabel (2017) "Una apuesta por el cambio en las series de ficción: La realidad virtual como estrategia narrativa al servicio de la inmersión del espectador". Anàlisi, 57 pp. 1-14. doi: 10.5565/rev/analisi.3105

Pallavicini, Federica, Argenton, Luca and Mantovani, Fabrizia (2016) "Virtual Reality Applications for Stress Management Training in the Military". Aerospace Medicine and Human Performance, 87(2) pp. 1021-1030. doi: 10.3357/AMHP.4596.2016

Pantelidis, Verónica S. (2010) "Reasons to Use Virtual Reality in Education and Training Courses and a Model to Determine When to Use Virtual Reality". Themes in Science and Technology Education, Special Issue. pp. 59-70. https://goo.gl/a9nHhf [Accessed 20 January 2019]

Parés, Narcís and Parés, Roc (2010) Realidad virtual. https://goo.gl/ nNxng3 [Accessed 20 January 2019]

Parkin, Simon (2014) "Will Virtual Reality Reshape Documentary Journalism?" MIT Technology Review. https://goo.gl/dEvfW9 [Accessed 20 January 2019]

Pascual, José Pedro (2004) "Ilusiones de realidad: de la perspectiva del Renacimiento a la Realidad Virtual". Bellas Artes, 2.

PCVR (January 1994) "Build A Head Tracker for \$25". PCVR Magazine, 13.

Perpiñá, Conxa, Botella, Cristina and Baños, Rosa (2003) "Virtual reality in eating disorders". European Eating Disorders Review, 11 pp. 261-278. doi: 10.1002/erv.520

Perpiñá, Conxa, Botella, Cristina, Baños, Rosa M., Marco Mariano, Jose H., Alcañiz Raya and Quero, Soledad (2009) "Body image and virtual reality in eating disorders: Exposure by virtual reality is more effective than the classical body image treatment?" CyberPsychology \& Behavior, 2(2) pp. 149-55. doi: 10.1089/ cpb.1999.2.149.

Pertaub, David-Paul, Slater, Mel and Baker, Chris (2002) “An experiment on public speaking anxiety in response to three different types of virtual audience". Presence: Teleoperators and virtual environments, 11 pp. 68-78. doi: 10.1162/105474602317343668

Platón (1966) Obras completas. Madrid: Aguilar.

Pletinckx, Daniel, Callebaut, Dirk, Killebrew, Ann E. and Silberman, Neil (2000) "Virtual-reality heritage presentation at Ename". IEEE MultiMedia, 7(2) pp. 45-48. doi: 10.1109/93.848427

Pimentel, Ken, \& Teixeira, Kevin (1995) Virtual reality: through the new looking glass. New York, McGraw Hill.

Potter, Leigh Ellen, Cartes, Lewis and Coghlan, Alexandra (2016) "Virtual Reality and Nature Based Tourism: An opportunity for operators and visitors". Proceedings of the 28th Australian Conference on Computer-Human Interaction, Launceston, Australia. pp. 652-654. doi: 10.1145/3010915.3011854

Pstoka, Joseph (1995) "Immersive training systems: Virtual reality and education and training". Instructional Science, 23(5) pp. 405-431. doi: 10.1007/BF00896880

Ramírez, María del Mar (2009) "La perspectiva artificial y su influencia en el desarrollo de la fotografia: De la perspectiva artificial a la perspectiva fotográfica". AISTHESIS, 45 pp. 25-38. doi: $10.4067 / \mathrm{S} 0718-71812009000100003$
Reaney, Mark (1996) "Virtual Scenography: The Actor, Audience, Computer Interface". Theatre Design and Technology, 45 pp25-38.

Rheingold, Howard (1994) Realidad virtual: los mundos artificiales generados por ordenador que modificarán nuestras vidas. Barcelona, Gedisa.

Riva, Giuseppe, Bacchetta, Monica, Baruffi, Margherita and Molinari Enrico(2002) "Virtual-reality-based multidimensional therapy for the treatment of body image disturbances in binge eating disorders: A preliminary controlled study". IEEE Transactions on Information Technology in Biomedicine, 6 pp. 224-234. doi: 10.1109/TITB.2002.802372

Riva, Giuseppe, Bacchetta, M., Cesa, Gian Luca, Conti, Sara and Molinari, Enrico (2003) "Six-month follow-up of in-patient experiential cognitive therapy for binge eating disorders". CyberPsychology \& Behavior, 6 pp. 251-258. doi: 10.1089/109493103322011533

Riva, Giuseppe, Melis, Luca and Bolzoni, Mirco (1997) "Treating Body-image disturbances". Communication of the ACM, $40 \mathrm{pp}$. 69-71. doi: $10.1145 / 257874.257890$

Rizzo, Albert A., Schultheis, Maria T., Kerns, Kimberly and Mateer, Catherine (2004) "Analysis of assets for virtual reality applications in neuropsychology". Neuropsychological Rehabilitation. 14(1) pp. 207-239. doi: 10.1080/09602010343000183

Roas, David (2009) "Lo fantástico como desestabilización de lo real: elementos para una definición”. In T. López \& F. A. Moreno (Eds.) Ensayos sobre ciencia ficción y literatura fantástica: actas del Primer Congreso Internacional de literatura fantástica y ciencia ficción. pp. 94-120 https://goo.gl/tAazhU [Accessed 20 January 2019]

Roussou, Maria (2001) "Immersive Interactive Virtual Reality in the Museum". Proceedings of Trends in Leisure Entertainment. https://goo.gl/QuLScR [Accessed 20 January 2019]

Rothbaum, Barbara Olasov, Hodges, Larry, Watson, Benjamin A., Kessler, G. Drew and Opdyke, Dan (2002) "Virtual reality exposure therapy for the treatment of fear of flying: A controlled investigation". Journal of Consulting and Clinical Psychology, 70 pp. 1112-1118. doi: 10.1037/0022-006X.70.5.1112

Rothbaum, Barbara O., Hodges, Larry F., Anderson, Page and Smith, Samantha (2002) "Twelvemonth follow-up of virtual reality and standard exposure therapies for the fear of flying". Journal of Consulting and Clinical Psychology, 70(2) pp. 42832. https://goo.gl/N5vAWB [Accessed 20 January 2019]

Rothbaum, Barbara O., Hodges, Larry F. and Kooper, Rob (1995a) "Effectiveness of computer-generated (virtual-reality) graded exposure in the treatment of acrophobia". American Journal of Psychiatry, 152(4) pp. 626-628. doi: 10.1176/ajp.152.4.626

Rothbaum, Barbara O., Hodges, Larry F., Kooper, Rob, Opdyke, Dan, Williford, James S. and North, Max (1995b) "Virtual-Reality Graded Exposure in the Treatment of Acrophobia: A Case Report". Behaviour Therapy, 26(3) pp. 547-554. doi: 10.1016/ S0005-7894(05)80100-5

Rothbaum, Barbara O., Hodges, Larry F., Smith, Samantha anf Price, Larry R. (2000) "A controlled study of virtual reality exposure therapy for fear of flying". Journal of consulting and Clinical Psychology, 68(6) pp. 1020-1026. doi: 10.1037/0022-006X.68.6.1020

Roy, S., Klinger, Evelyne, Légeron, P. and Nugues, P. (2003) "Definition of a VR-based protocol to treat social phobia". CyberPsychology \& Behavior, 6 pp. 411-420. doi: 10.1089/109493103322278808

Russo, Eduardo (2012) "El 3D una vez más. ¿Esta vez sí? El cine en relieve ante los espectadores contemporáneos". Cuadernos del Centro de Estudios en Diseño y Comunicación, 39 pp. 269-281. https://goo.gl/fl6Va7 [Accessed 20 January 2019]

Scatena, Sofia, Russo, Gian Nicolo and Riva, Giuseppe (2016) "Virtual Reality vs Television vs Web Exposure: The impact on Brand Experience". A preliminary study. Annual Review of $\mathrm{Cy}$ bertherapy and Telemedicine, 14 pp. 211-213. https://goo.gl/ fvOyZ3 [Accessed 20 January 2019]

Seymour, Neal E., Gallagher, Anthony G., Roman, Sanziana A., O'Brien, Michael K., Bansal, Vipin K., Andersen, Dana K. and Satava, Richard M. (2002) "Virtual reality training improves operating room performance - Results of a randomized, doubleblinded study". Annals of Surgery, 236(4) pp. 458-464. 
Sharar, Sam R., Alamdari, Ava, Hoffer, Christine, Hoffman, Hunter G., Jensen, Mark P. and Patterson, David R. (2016) "Circumplex Model of Affect: A Measure of Pleasure and Arousal During Virtual Reality Distraction Analgesia”. Games for Health Journal, 5(3) pp. 197-202. doi: 10.1089/g4h.2015.0046.

Sherman, William and Craig, Aalan (2003) Understanding virtual reality. San Francisco, Morgen Kaufman Publishers.

Slater, Mel, Pertaud, David-Paul and Steed, Anthony (1999) "Public speaking in virtual reality: Facing an audience of avatars". IEEE Computer Graphics and Applications, 19(2) pp. 6-9. doi: 10.1109/38.749116

Silva, Andreia, Machado, Ricardo, Simões Vanessa and Do Céu, Maria (2015) "A terapia da realidade virtual e a pessoa queimada: redução da dor nos cuidados à ferida - Uma revisão integrativa da literatura". Queimaduras, 14(1) pp. 35-42. https:// goo.gl/Bw8o7I [Accessed 20 January 2019]

Simó, Águeda (2001) Aplicación de la realidad virtual en la creación artística (PhD thesis, Universidad del País Vasco) https://goo.gl/EsZ0re [Accessed 20 January 2019]

Simó, Águeda (2012) "Las nuevas tecnologías en la creación artística: La realidad virtual como fábrica de realidades". Fabrikart, 2 pp. 98-106. https://goo.gl/mS1Vf [Accessed 20 January 2019]

Sorene, P. (2014) "Jaron Lanier's EyePhone: Head and Glove Virtual Reality in the 1980s". Flashback. https://goo.gl/CJ1c8Z [Accessed 20 January 2019]

Statista (2019) Número de usuarios de realidad virtual a nivel mundial desde 2015 hasta 2018 (en millones) https://bit.ly/2H5mBsJ [Accessed 20 January 2019]

Steinhart, Eric (1997) "Leibniz's palace of the fates: A seventeenthcentury virtual reality system". Presence: Teleoperators \& Virtual Environments, 6(1) pp. 133-135. doi: 10.1162/pres.1997.6.1.133

Stephens, Diana (2015) 3-D and the Cinema of Distractions: The Rise of 3-D as a Gimmick, and Its Inevitable Fall (PhD thesis, Carleton University) https://goo.gl/EZcBfR [Accessed 20 January 2019]

Sturman, David J. and Zeltzer, David (1994) "A Survey of Glovebased Input". IEEE Computer Graphics and Applications, 14(1) pp. 30-39. doi: 10.1109/38.250916

Sturm, Lana, Windsor, John A., Cosman, Peter, Cregan, Patrick C., Hewett, Peter J. and Maddern, Guy J. (2008) "A systematic review of skills transfer after surgical simulation training". Annals of Surgery, 248(2) pp. 166-179. doi: 10.1097/SLA.0b013e318176bf24

Sutherland, Ivan (1965) "The Ultimate Display". Proceedings IFIP Congress, 506-508. https://goo.gl/Jleurr [Accessed 20 January 2019]

Sutherland, Ivan (1968) "A Head-Mounted Three-Dimensional Display". AFIPS Conference Proceedings, 33(1) pp. 757-764. https://goo.gl/RDZwL6 [Accessed 20 January 2019]

Thorsteinsson, Gisli (2013) "Developing and understanding of the pedagogy of using a Virtual Reality Learning Environment (VRLE) to support innovation education". In L. V. Shavinina (Ed.), The Routledge International Handbook of Innovation Education. pp. 456-470. New York, Routledge.

Thurley, Kay and Ayaz, Asli (2016) "Virtual reality systems for rodents”. Current Zoology, 63(1) pp. 109-119. doi: 10.1093/ cz/zow070

Tudor, Sarah, Carey, Stephanie and Dubey, Rajiv (2015) "Development and evaluation of a dynamic virtual reality driving simulator". Proceedings of the 8th ACM International Conference on PETRA '15, Pervasive Technologies Related to Assistive Environments. doi: 10.1145/2769493.2769593

Velev, Dimiter, and Zlateva, Plamena (2017) "Virtual Reality Challenges in Education and Training". International Journal of Learning and Teaching, 3(1) pp. 33-37. doi: 10.18178/ ijlt.3.1.33-37

Vera, Guillermo, Ortega, José Antonio and Burgos, María Ángeles (2003) "La realidad virtual y sus posibilidades didácticas". $R e$ vista científica tecnológica de Educación y Comunicación en la Sociedad del Conocimiento, 2. doi: 10.18178/ijlt.3.1.33-37

Villegas, Andrés (2012) Realidad virtual en el sector de la construcción (MA Dissertation, Universidad EAFIT) https://goo. gl/OL9DcZ [Accessed 20 January 2019]

Wade, Nicholas J. and Ono, Hiroshi (2012) "Early studies of binocular and stereoscopic vision". Japanese Psychological Research, 54(1) pp. 54-70. doi: 10.1111/j.1468-5884.2011.00505.x

Wald, J., \& Taylor S. (2000) "Efficacy of virtual reality exposure therapy to treat driving phobia: a case report". Journal of Behaviour Therapy and Experimental Psychiatry, 31 pp. 249-257. doi: 10.1016/S0005-7916(01)00009-X

Wald, Jaye and Taylor, Steven (2003) "Preliminary research on the efficacy of virtual reality exposure therapy to treat driving phobia". CyberPsychology \& Behavior, 6(5) pp. 459-465. doi: 10.1089/109493103769710488

Walshe, David G., Lewis, Elizabeth J., Kim, Sun I, O’Sullivan, Kathleen and Wiederhold, Brenda Kay (2003) "Exploring the use of computer games and virtual reality in exposure therapy for fear of driving following a motor vehicle accident". CyberPsychology \& Behavior, 6(3) pp. 329-334. doi: 10.1089/109493103322011641

Weigel, A. David and Moratis, Christina D. (2017) "Virtual Reality Astronomy Education Using AAS WorldWide Telescope and Oculus Rift". American Astronomical Society, 229. https://goo. $\mathrm{gl} / \mathrm{mmpdLk}$ [Accessed 20 January 2019]

Wheatstone, Charles (1838) "Contributions to the Physiology of Vision. Part the First. On Some Temarkable, and Hitherto Unobserve, Phenomena of Binocular Vision". Philosophical Transactions, 128 pp. 371-394. doi: 10.1098/rstl.1838.0019

Wiederhold, Brenda K. (1999) "A comparison of imaginal exposure and virtual reality exposure for the treatment of fear of flying". Dissertation Abstracts International: Section B: The Sciences $y$ Engineering, 60(4) pp. 18-37.

Wiederhold, Brenda K., Gervitz, Richard and Wiederhold, Mark D. (1998) "Fear of flying: A case report using virtual reality therapy with physiological monitoring". CyberPsychology \& Behavior, 1 pp. 97-103. doi: 10.1089/cpb.1998.1.97

Wojciechowski, Rafal, Walczak, Krzysztof, White, Martin and Cellary, Wojciech (2004) "Building Virtual and Augmented Reality Museum Exhibitions". Proceedings of the ninth international conference on 3D Web technology, Monterey, California. doi: $10.1145 / 985040.985060$

Yang, Yang, Leung, Howard, Yue, Li Hua and Deng, Li Qun (2012) "Automatic dance lesson generation". IEE Transactions on Learning Technologies, 5(3) pp. 191-198. doi: 10.1109/TLT.2011.31

Yol, Jae and Shin, Im (2009) "The Effects of Virtual Reality Advertisement on Consumer's Intention to Purchase: Focused on Rational and Emotional Responses". Asia Pacific Journal of Information Systems, 19(4) pp. 101-124. https://goo.gl/aAV681 [Accessed 20 January 2019]

Zapatero, Daniel (2007) Aplicaciones didácticas de la realidad virtual al Museo Pedagógico de Arte Infantil (PhD thesis, Universidad Complutense de Madrid) https://goo.gl/RxEdyT [Accessed 20 January 2019]

Zapatero, Daniel (2011) "La realidad virtual como recurso y herramienta útil para la docencia y la investigación”. Revista TE\&ET, 6 pp. 17-23. https://goo.gl/raaH5y [Accessed 20 January 2019] 